10. Thornbury, S. How to Teach Vocabulary. - Harlow: Longman, 2002. - 185 p.

\title{
REFERENCES
}

1. Medodyka navchannia inozemnych mov i kultur: teoriia i praktyka [Methodology of teaching foreign languages and cultures: theory and practice]: pidruchnyk dlia stud. klasychnykh, pedahohichnych i linhvistychnykh universytetiv / Bihych O. B., Borysko N.F., Boretska H.E. ta in. / za zahaln. red. S. Yu. Nikolaievoii. - K.: Lenvit, 2013. - 590c.

2. Teoriia i praktyka formuvannia inshomovnoi profesiino oriientovanoi kompetentnosti $\mathrm{v}$ govorinni $\mathrm{u}$ studentiv nelinhvistychnyh spetsialnostei [Theory and practice of formation of foreign language professional-oriented competence in speaking among students of non-linguistic specialties]: kolektyvna monohrafiia za zah. i nauk. red O. B. Bihych / O. B. Bihych, L. V.Bondar, M. M. Voloshynova, L. O. Maksymenko, O. M. Ohui, I. O. Simkova, Ya. V. Okopna. - Kyiv: Vyd. tsentr KNLU, 2013. - 383 p.

3. Anderson, L., \& Krathwohl, D. A. Taxonomy for Learning, Teaching and Assessing: A Revision of Bloom's Taxonomy of Educational Objectives. - New York: Longman, 2001. - 352p.

4. Basturkmen H. Ideas and Options in English for Specific Purposes / Helen Basturkmem. - London: Lawrence Erlbaum Associates, 2006. - 186 p.

1. 5. Dudley-Evans, T. Developments in English for Specific Purposes: a multidisciplinary approach. Cambridge: Cambridge University Press, 2009. - 317p.

5. Harmer J. The Practice of English Language Teaching / J. Harmer. $-3^{\text {rd }}$ ed. $-[$ S. 1.]: Pearson Education Limited, 2001. - $371 \mathrm{p}$.

6. Hughes, Arthur. Testing for Language Teachers. - Glasgow: Cambridge University Press, 1989. - 172p.

2. 8. Hutchinson Tom, and Waters Alan. English for Specific Purposes: A Learning - centred Approach Cambridge [Cambridgeshire: Cambridge UP, 1987. Print. - 183p.

8. Longman Dictionary of Language Teaching and Applied Linguistics / Jack C. Richards, Richard Schmidtt. - 4th ed. - Harlaw: Pearson Education Limited, 2010. - 645 p.

9. Tarone E. Focus on the Language Learner / E. Tarone, G. Yule. - Oxford University Press, 1995. - 206 p. 10. Thornbury, S. How to Teach Vocabulary. - Harlow: Longman, 2002. - 185 p.

УдК 378.147:811.111

AGNESSA TOMASHEVSKA

https://orcid.org/0000-0003-3574-5945 agnessat1992@gmail.com

Postgraduate Student

Ternopil Volodymyr Hnatiuk National Pedagogical University

Ternopil, 2 Maksyma Kryvonosa St.

\section{DEVELOPING PROSPECTIVE PHARMACISTS' ENGLISH LEXICAL COMPETENCE IN READING AND SPEAKING THROUGH EXERCISES FOR SELF-DIRECTED STUDY}

The article grounds the main principles of developing prospective pharmacists' English lexical competence in reading and speaking through self-directed study: integrated development of lexical knowledge, skills and lexical awareness in reading and speaking (exercises should be directed to integrated development of all the components of lexical competence), profession-oriented learning (all the texts deal with the topics within the professional area, the main focus is made on professional terms, typical professional situations of intercultural communication), visualization (the vocabulary presented should be visualized to help students create mental pictures), consciousness (e.g., comparing to the corresponding terms in the languages of origin), development of students' strategic awareness, considering lexical unit features. Stages of developing prospective pharmacists' English lexical competence in reading and speaking through self-directed study have been determined: preparatory, which entails semantization of new lexical units and is divided into two sub-stages: the first - getting acquainted with new words out of context (should be applied only for professional terms), the second - getting acquainted with new words in context and building strategic awareness; training - implies automatizing students' actions with new lexical units on the levels of a word, word combination, phrase, sentence, suprasegmental unit; usage - activating students' actions with new lexical units on the text level. A subsystem of exercises for developing prospective pharmacists' English lexical competence in reading and speaking through self-directed study has been worked out. It contains three groups of exercises which correlate with the stages and are subdivided into subgroups. 
Keywords: prospective pharmacists, English lexical competence in reading and speaking, self-directed study, subsystem of exercises, stages, principles.

АГНЕССА ТОМАШЕВСЬКА

аспіранта

Тернопільський національний педагогічний університет імені Володимира Гнатюка

м. Тернопіль, вул. Максима Кривоноса 2

\title{
ФОРМУВАННЯ У МАЙБУТНІХ ФАРМАЦЕВТІВ АНГЛОМОВНОЇ ЛЕКСИЧНОЇ КОМПЕТЕНТНОСТІ В ЧИТАННІ ТА ГОВОРІННІ ЗА ДОПОМОГОЮ ВПРАВ ДЛЯ САМОСТІЙНОЇ РОБОТИ
}

\begin{abstract}
Обтрунтовано принщипи формування у майбутніх фармащевтів англомовної лексичної компетентності в читанні та говорінні у процесі самостійної роботи: інтегрованого формування лексичних знань, навичок і лексичної усвідомленості у читанні та говорінні; професійно орієнтованого навчання (зосередженість на темах, ситуаціях професійного спілкування, відповідних термінах); візуалізації (сприятиме створенню в студентів ментальних образів, моделей); свідомості (наприклад, порівняння термінів англійською мовою з латинськими відповідниками); розвитку стратегічної усвідомленості, урахування особливостей лексичних одиниць. Визначено три етапи формування ияієї компетентності у зазначеному прочесі: підготовчий, який спрямований на семантизацію нових лексичних одиниць $і$ поділяється на два підетапи: периий - ознайомлення з новими лексичними одиницями поза контекстом (лише для термінологічної лексики), другий - ознайомлення з новими словами у контексті $i$ иілеспрямований розвиток стратегічної усвідомленості; автоматизація дій студентів з лексичними одинииями на рівні слова, словосполучення, фрази, речення, надфразової єдності; використання вивчених лексичних одиниць на текстовому рівні. На другому і третьому етапах передбачено заохочення студентів до використання різних стратегій і подальшого аналізу їхньої ефективності та дочільності. Обтрунтовано вимоги до вправ для формування англомовної лексичної компетентності. 3 урахуванням визначених етапів запропоновано підсистему вправ для формування у майбутніх фармацевтів англомовної лексичної компетентності в читанні та говорінні у процесі самостійної роботи. Розроблена підсистема містить три групи вправ, які корелюють з етапами і передбачають підгрупи вправ. Вказано, щчо автоматизачія дій студентів з новими лексичними одиничями на рівні слова, словосполучення, фрази, речення, надфразової єдності здійснюється окремо для читання та говоріння, а на рівні тексту - спочатку окремо для читання та говоріння, а потім інтегровано.
\end{abstract}

Ключові слова: майбутні фармацевти, англомовна лексична компетентність в читанні та говорінні, самостійна робота, підсистема вправ, етапи, принципи.

АГНЕССА ТОМАШЕВСКАЯ

аспирантка

Тернопольский национальный педагогический университет имени Владимира Гнатюка г. Тернополь, ул. Максима Кривоноса, 2

\section{ФОРМИРОВАНИЕ У БУДУЩИХ ФАРМАЦЕВТОВ АНГЛОЯЗЫЧНОЙ ЛЕКСИЧЕСКОЙ КОМПЕТЕНТНОСТИ В ЧТЕНИИ И ГОВОРЕНИИ С ПОМОЩЬЮ УПРАЖНЕНИЙ ДЛЯ САМОСТОЯТЕЛЬНОЙ РАБОТЫ}

Обоснованы принщипь формирования у будущчих фармацевтов англоязычной лексической компетентности в чтении и говорении в процессе самостоятельной работь: интегрированное формирование лексических знаний, навыков и лексической осознанности в чтении и говорении; професссионально ориентированного обучения (сосредоточенность на темах, ситуациях профессионального общения, соответствующих терминах); визуализации (способствует созданию у студентов ментальных образов, моделей); сознательности (например, сравнение терминов на английском языке с соответствующими латинскими терминами); развитие стратегичной осознанности, учет особенностей лексических единиц. Определены три этапы формирования у будущих фармацевтов англоязычной лексической компетентности в чтении и говорении: подготовительный, который направлен на семантизацию новых лексических единии и делится на два подэтапа: первый ознакомление с новыми лексическими единицами вне контекста (только для терминологической 
лексики), второй - ознакомление с новыми лексическими единицами в контексте и целенаправленное развитие стратегической осознанности; автоматизация действий студентов с лексическими единицами на уровне слова, словосочетания, фразы, предложения, сверхфразового единства; использование выученных лексических единии на текстовом уровне. С учетом выделенных этапов предложено подсистему упражнений для формирования у будущих фармацевтов англоязычной лексической компетентности в чтении и говорении в процессе самостоятельной работы. Разработанная подсистема содержит три группь упражнений, которые соотносятся с этапами и, $в$ свою очередь, включают подгруппы упражнений.

Ключевые слова: будущие фармацевты, англоязычная лексическая компетентность в чтении и говорении, самостоятельная работа, подсистема упражнений, этапы, принципь.

Nowadays it has become extremely important for the health care professionals to know at least one foreign language, predominantly English, as it enables them to get valuable information from the authentic sources which is often in English, communicate with colleagues from other countries, actively participate in different events, for example, scientific conferences and thus expand professional knowledge and develop skills, improve career prospects.

Lexical competence is an important component of communicative language competence which implies student's ability to understand words and "choose an appropriate expression from their repertoire" $[12$, p. 134] demonstrating the necessary breadth and variety [12, p. 132] to convey the appropriate meaning.

The question of developing vocabulary skills has been the focus of the investigation of many researches (V. Borshchovetska, I. Chorna, A. Kotlovskyi, I. Lypska, A. Paletska, I. Zadorozhna, R. Gairns, S. Redman, V. P. Takač,). Teaching foreign language to health professionals has also been the area of concern of modern scientists. Thus, L. Biretska, L. Krysak, L. Rusalkina, Ch. Tsymbrovska and others studied developing different aspects of ESP communicative competence of prospective doctors. T. Horpinich focused on forming ESP reading skills of future pharmacists. However, there is still lack of investigations on teaching ESP prospective pharmacists. Besides, the analysis of modern scientific literature shows that the methodology of developing prospective pharmacists' English lexical competence has not been developed yet. In the article we will focus on lexical competence in reading and speaking as integrated formation of such skills may facilitate learning and improve the results.

Because of the limited amount of classes much attention should be paid to self-directed study which can contribute greatly to the development of students' English lexical competence.

The purpose of the article is to ground the main principles of teaching and present the subsystem of exercises for self-directed study aimed at developing prospective pharmacists' English lexical competence in reading and speaking.

Teaching lexical skills (as well as other skills) should be based on principles which can be viewed as requirements that ensure the effectiveness of teaching and learning.

The analysis of scientific literature shows that usually scientists emphasize the following principles in teaching vocabulary $[1$, p. $6-7 ; 2$, p. $85-91 ; 5$, p. $65-69 ; 8$, p. 66]: visibility, consciousness, focus on typical professional situations, autonomy, individualization, consistency, systemic character, interdisciplinary approach, cognitive activity, dominant role of exercises, considering mother tongue, and others.

All of them can be applied to our investigation, however, we will focus on those which are of main importance for developing prospective pharmacists' English lexical competence in reading and speaking: integrated development of lexical knowledge, skills and lexical awareness in reading and speaking, profession-oriented learning, visualization, consciousness, development of students' strategic awareness, considering lexical unit features.

The principle of integrated development of lexical knowledge, skills and lexical awareness in reading and speaking means that the subsystem of exercises should be directed to integrated development of all the components of lexical competence (lexical knowledge, lexical skills and lexical awareness) as well as integrated development of lexical skills in reading and speaking.

Lexical knowledge presupposes knowledge of form (spoken, written, parts of the word), meaning (Is there a Ukrainian word with almost the same meaning?), use (grammatical functions (predictable grammar patterns with the word), collocation (Does the word have the same collocations as the Ukrainian word?), constraints on use (restrictions, whether they are the same as the Ukrainian word of similar meaning)) [15, p. 49-50]. Lexical skills are divided into receptive (reading - 
recognizing the words and their semantization, guessing the meaning of the word from the context, word analysis, comparing with similar Ukrainian and Latin words, differentiating similar words) and reproductive (speaking - using new lexical units in oral communication, correct word combination in phrases and sentences, assessment of the correctness of the words usage) [3, p. 512-513]. Lexical awareness is the ability to analyse main difficulties of lexical competence acquisition, evaluate the usage of lexical units, analyse own mistakes [6, p. 112; 7, p. 21].

Lexical skills undergo integrated development on all the stages. At first students get acquainted with new lexical units (in the context or beyond it), then they train to recognize and use new lexical units on the level of a word, word combination, phrase, sentence, supra phrasal unit, text.

Profession-oriented learning means that all the texts deal with the topics within the prefossional area, the main focus is made on professional terms, typical professional situations of intercultural communication. The content and activities should correlate with students' professional needs and interests. In such a case students will be not only better trained to perform their duties in different situations, but also motivated to learn English as they will see the practical importance and ways of using the language at work. The principle of profession-oriented learning implies strong connection with the professional subjects, their content, which develops students' understanding of meaningful connections among English and other disciplines.

According to the principle of visualization the vocabulary presented should be visualized to help students create mental pictures. L. Biretska proved the expediency of using mind maps at all stages of teaching vocabulary to prospective doctors [1, p. 22]. Mind maps can be viewed as graphic organizers with the main concept or word in the centre and associated or related words radiating from it. It does not mean that teachers should always provide students with mind maps. They may demonstrate this strategy to students, and prospective pharmacists must be involved in producing mind maps themselves, which will help them better memorise the words, understand their relations with other words, see connection with prior knowledge, create mental links, improve memory retention. It is very important for memorizing new vocabulary, its comprehension and use in speech production. For example, words are organized in semantic fields so producing speech a speaker can select a word easily from a particular topic area; similar sounding words are also grouped together, which is useful for comprehension [9, p. 193].

The principle of consciousness means emphasis on meaningful learning when new symbols, concepts are incorporated within students' cognitive structure. As pharmacy and medical terminology is still based on Greek and Latin, students should learn them consciously comparing to the corresponding terms in the languages of origin.

Considering lexical unit features means taking into account the peculiarities of the word while presenting or memorizing it. For example, some words can be understood from the context (e.g. 'Aspirin may cause side effects. Tell your doctor if any of these symptoms are severe or do not go away: nausea, vomiting, stomach pain ... [10]). Others may be understood from the analysis of the prefix, suffix and the root. For example, ultramicrotomy: ultra = excess, beyond; micro = tiny; tomy = cutting (the technique of cutting into very thin pieces) [14, p. 222]. Some words are similar to corresponding Latin or/and Ukrainian ones (for example, nerve (Latin-nervus, Ukrainian - нерв), oil (Latin-oleum)).

Development of students' strategic awareness means teaching students to use effective strategies which are viewed as actions that learners consciously select to improve the foreign language learning or its use or both $[11$, p. 5]. As many scientists, who categorise language learning strategies into cognitive, metacognitive, social and affective $[11 ; 16 ; 19]$, in L2 vocabulary acquisition we consider using cognitive, metacognitive, social, affective and communicative strategies. On the basis of modern literature analysis $[4 ; 18]$ and the results of the questionnaire which was suggested to the students of Bukovinian state medical university we have selected and determined strategies important for the development of prospective pharmacists' English lexical competence in reading and speaking. Cognitive strategies concern mental actions [17] and include: analysis of the structure, comparison of Latin or/and Ukrainian equivalents, synthesis, linking with prior knowledge, memorising (imitation, writing down words, making sentences, using word cards, grouping, associating, connecting the word to a personal experience, semantic mapping, using keywords, representing in memory, oral repetition, visual repetition, structured reviewing, using words in various contexts) [4, p. 73; 18, p. 67-69]). 
Metacognitive strategies presuppose planning, goals setting, monitoring and evaluation of the learning process and results [19]. They are based on metacognitive knowledge which includes person knowledge (what students know about learning and themselves as learners), task knowledge (its objectives, skills necessary to fulfill the task) and strategic knowledge (knowledge of the best strategies and language learning itself, which helps in selecting strategies) [18, p. 53-54]. Metacognitive strategies include: planning for vocabulary learning, dictionary use strategies, keeping a vocabulary notebook which may include examples of using words in the sentences, mind maps etc., consulting a reference source, using English-language resources, testing knowledge with word tests, repeating the word over time, regular repeating outside classroom [18, p. 69-71].

Social strategies presuppose cooperation with other students and the teacher, which helps learners complete the task and develop target skills: asking for a L1 translation, asking a teacher for a sentence with the new word, asking groupmates for meaning, discovering the meaning through group work activity, interaction with native speakers, getting someone to test the knowledge.

Communicative strategies in terms of our investigation include mainly compensation strategies (guessing the meaning of the word by morphological analysis, using context, multiple reading to guess the meaning of the words, paraphrasing) [4, p. 72].

The next step is to determine stages of developing prospective pharmacists' English lexical competence in reading and speaking.

Taking into account the views of modern scientists [1, p. 10;6, p. 223], we have defined the following stages:

Preparatory, which entails semantisation of new lexical units and is divided into two substages: the first - getting acquainted with new words out of context (should be applied only for professional terms), the second - getting acquainted with new words in context and building strategic awareness.

Training - implies automatizing students' actions with new lexical units on the levels of a word, word combination, phrase, sentence, suprasegmental unit.

Usage - activating students' actions with new lexical units on the text level.

The suggested subsystem of exercises for self-directed study of developing prospective pharmacists' English lexical competence in reading and speaking correlates with the stages and meets the following requirements:

- all the exercises are motivated (they contain instructions with explanation why students should do the exercise);

- the purpose of each exercise is clearly stated in order to help students understand why they should do it and set own individual goals;

- most exercises contain a reflective component which encourages their self-evaluation and self-control;

- exercises entail purposeful development of strategic awareness on the first stage (second substage) and further attention to strategy use on the next stages;

- most exercises presuppose self-control, some combine teacher's control and self-control.

The subsystem contains three groups of exercises which correlate with the stages and are subdivided into subgroups:

Group 1. Word semantization.

Subgroup 1.1. New words semantization out of context (only for professional terms).

Subgroup 1.2. New words semantization in context.

Subgroup 1.3. Development of strategic awareness.

Group 2. Forming lexical skills in reading and speaking on the levels of a word, word combination, phrase, sentence, suprasegmental unit.

Subgroup 2.1. Forming lexical skills in reading on the levels of a word, word combination, phrase, sentence, suprasegmental unit.

Subgroup 2.2. Forming lexical skills in speaking on the levels of a word, word combination, phrase, sentence, suprasegmental unit.

Group 3. Forming lexical skills in reading and speaking on the text level.

Subgroup 3.1. Forming lexical skills in reading on the text level.

Subgroup 3.2. Forming lexical skills in speaking on the text level.

Subgroup 3.3. Integrated development of lexical skills in reading and speaking on the text level. Here are some examples of the exercises developed on the basis of modern literature [13]. 
Example 1, subgroup 1.1.

Purpose: developing skills of new words semantization using Latin or Ukrainian equivalents.

Instruction: It is important to be able to guess the meanings of different terms using Latin or Ukrainian equivalents. Guess the meaning of the following terms using Latin or Ukrainian equivalents.

Reflection: Think how you guessed. Write at least 5 other English terms which are similar to Latin or Ukrainian equivalents.

A capsule, grain, injection, powder, dose, exhaustion, extract, fever, inflammation

Example 2, subgroup 1.2.

Purpose: developing skills of new words semantization using context.

Instruction: It is important to be able to guess the meanings of different terms from the context and using Latin or Ukrainian equivalents. Guess the meaning of the following terms using Latin or Ukrainian equivalents and the context..

1. The patient feels a localized pain in the chest. The pain is usually spasmodic and piercing.

2. The patient tells the pharmacist that she has a burning sensation when she urinates and feels like she has to urinate all the time.

3. The patient tells the pharmacist that she is allergic to antibiotics and tomatoes, is lactose intolerant, and is on birth control pills.

4. Hepatitis B is transmitted through contact with blood and bodily fluids of an infected person...

Reflection: Think what helped you to guess the meaning of the underlined words.

Example 3, subgroup 1.3.

Purpose: developing linguistic awareness.

Instruction: It is useful to keep a vocabulary notebook which helps to memorise new words and repeat them in future. The vocabulary notebook should include components which will improve memorizing and understanding how to use words correctly. The notes of the words may include: 1) translation of words into Ukrainian; 2) Latin equivalents; 3) examples of using words in the sentences; 4) mind maps which demonstrate links and associations with other words etc. Write down the new words into the vocabulary. Add all the necessary components.

Reflection: Compare your notes to the partners'. Would you loke to add anything to your notes? How would you recommend your partner to improve the notes?

Example 4, subgroup 2.1.

Purpose: forming lexical skills in reading on the levels of a word.

Instruction: To comprehend written information it is of utmost importance to know the meanings of the terms. Match the words to their definitions.

\begin{tabular}{|l|l|}
\hline 1) to be hoarse & a) small bluish-black spots on the body \\
\hline 2) bruises & $\begin{array}{c}\text { b) to empty the contents of the stomach } \\
\text { through the mouth }\end{array}$ \\
\hline 3) bottle-feeding & c) to become wider and more open \\
\hline 5) to dilate & $\begin{array}{l}\text { d) a small, flat sweet that you suck to make } \\
\text { a cough or sore throat less severe }\end{array}$ \\
\hline 6) lozenge & e) to speak with a harsh, low sound \\
\hline
\end{tabular}

Example 5, subgroup 2.2.

Purpose: forming lexical skills in speaking on the levels of a word, sentence.

Instruction: If you want to speak fluently, you should know and be able to use medical terms. Continue the following sentences.

Example: Symptoms of cirrhosis include ...

Possible answer: Symptoms of cirrhosis include swelling in the legs, fluid in the abdomen, intense itching, fatigue, and nausea.

Reflection: Compare your answer to the partners'. Do you want to change your answer or add anything to it?

Symptoms of hepatitis A include ... .

To relieve headache you should use ...

To stop or prevent vomiting one should ...

Spasmolitics are used to ...

If you feel dizzy, you should ...

Наукові записки. Серія: педагогіка. - 2018. - № 2. 
Example 6, subgroup 3.2.

Purpose: forming lexical skills in speaking on text levels.

Instruction: In future you may have to speak at conferences on different professional topics. You are to speak at the conference about the future of pharmacy. Prepeare the speech and remember that you should use as many new words as possible.

Reflection: Record your answer and analyse it using the criteria.

Example 7, subgroup 3.3.

Purpose: developing integrated lexical skills in reading and speaking.

Instruction:

Student 1. You are not feeling well. You have come to the drugstore and want to buy some medicines to relieve your symptoms and recover. Explain your symptoms to the pharmacist and ask to recommend you some medicines. Read the instruction and ask the pharmacist any questions you may have on using the medicines.

Student 2. Listen to the patients' symptoms, read the information about some medicines and recommend the patient what he/she should use. Instruct patient on how and when to take the suggested medicines. Encourage him/her to read information about the medicines and answer their questions.

All in all, we have grounded the main principles of developing prospective pharmacists' English lexical competence in reading and speaking through self-directed study (integrated development of lexical knowledge, skills and lexical awareness in reading and speaking, profession-oriented learning, visualization, consciousness, development of students' strategic awareness, considering lexical unit features); determined the stages of developing prospective pharmacists' English lexical competence in reading and speaking through self-directed study (preparatory, which entails semantization of new lexical units and is divided into two sub-stages: the first - getting acquainted with new words out of context (should be applied only for professional terms), the second - getting acquainted with new words in context and building strategic awareness; training that implies automatizing students' actions with new lexical units on the levels of a word, word combination, phrase, sentence, suprasegmental unit; usage which presupposes activating students' actions with new lexical units on the text level); suggested a subsystem of exercises which contains three groups of exercises that correlate with the stages and are subdivided into subgroups; presented the examples of exercises from all the groups.

\section{ЛITЕРАТУРА}

1. Бірецька Л. С. Формування англомовної лексичної компетентності майбутніх лікарів у професійно орієнтованому читанні: автореф. дис. ... канд. пед. наук: 13.00 .02 / Л. С. Бірецька. - K., 2015. $-22 \mathrm{c}$.

2. Жовтюк Н. П. Методика формування у майбутніх учителів лексичної компетентності у процесі навчання англійської мови після німецької: дис. ... канд. пед. наук: 13.00 .02 / Н. П. Жовтюк. Тернопіль, 2015. $-317 \mathrm{c}$.

3. Задорожна І. П. Теоретико-методичні засади організації самостійної роботи майбутніх учителів 3 оволодіння англомовною комунікативною компетенцією: дис. ... д-ра пед. наук: 13.00.02 / I. П. Задорожна. - К., 2012. - 770 c.

4. Задорожна I. П. Developing Language Learning Strategies and Self-Evaluation Skills as Key Factors in Promoting Prospective FL Teachers' Autonomy / I. П. Задорожна // Педагогічний альманах: збірник наукових праць. - Херсон, 2016. - Вип. 29. - С. 69-75.

5. Котловський А. М. Формування англомовної лексико-граматичної компетентності в говорінні майбутніх економістів у процесі самостійної роботи: дис. ... канд. пед. наук: 13.00.02 / А. М. Котловський. - Тернопіль, 2017. -253 с.

6. Методика навчання іноземних мов і культур: теорія і практика: підручник для студ. класичних, педагогічних і лінгвістичних університетів / Бігич О. Б., та ін. / за ред. С. Ю. Ніколаєвої. - К.: Ленвіт, 2013. -590 с.

7. Палецька А. В. Методика формування німецькомовної лексичної компетентності майбутніх учителів на основі автентичних художніх творів: дис. ... канд. пед. наук: 13.00 .02 / А. В. Палецька Тернопіль, 2018. - 405 с.

8. Чорна І. Ю. Формування у майбутніх маркетологів англомовної лексичної компетентності в письмі засобом кейс-технології: дис. ... канд. пед. наук: 13.00.02 / І. Ю. Чорна. - Тернопіль, 2017. - 268 с.

9. Aitchison J. Words in the Mind: an Introduction to the Mental Lexicon / J. Aitchison. Oxford: Blackwell, 1987. $229 \mathrm{p}$.

$\begin{aligned} & \text { 10. Aspirin. } \\ & \text { https://medlineplus.gov/druginfo/meds/a682878.html. }\end{aligned}$
[Electronic 
11. Cohen A. D. Strategies in Learning and Using a Second Language. New York: Addison Wesley Longman, 1998. 295 p.

12. Common European Framework of References for Languages: learning, teaching, assessment. Companion Volume with new Descriptors. 2018. $235 \mathrm{p}$. [Electronic resource]. Available at: https://www.coe.int/en/web/common-european-framework-reference-languages.

13. Györffy M. English for Doctors. IDIÓMA Bt, 2001. 225 p.

14. Hedge T. Teaching and Learning in the Language Classroom / T. Hedge: Oxford, Oxford University Press, 2000. 448p.

15. Mićić S. Languages of medicine - present and future. JAHR. 2013. Vol. 4. No. 7. P. 217-233.

16. Nation P. Teaching Vocabulary. The Asian EFL Journal. 2005. Vol. 7. Issue 3. P. 47-54.

17. O’Malley M. J., Chamot A. U. Learning Strategies in Second Language Acquisition. Cambridge: Cambridge Applied Linguistics, 1990. 276 p.

18. Rubin J. Learner strategies: Theoretical assumptions, research history and typology. Learner Strategies in Language Learning; A. Wenden and J. Rubin (eds). New York: Prentice Hall, 1987. P. 15-30.

19. Takač V. P. Vocabulary Learning Strategies and Second Language Acquisition. Multilingual Matters LTD, 2008. 197 p.

20. Williams M., Burden R. L. Psychology for Language Teachers. Cambridge: Cambridge University Press, 1997. $252 \mathrm{p}$.

\section{REFERENCES}

1. Bireczka L. S. Formuvannya anglomovnoyi leksychnoyi kompetentnosti majbutnix likariv u profesijno oriyentovanomu chytanni: avtoref. dys. ... k-ta ped. nauk: 13.00.02 [Forming English Lexical Competence of Prospective Doctors' Professional Reading]. Kyiv, 2015. 22 p.

2. Zhovtyuk N. P. Metodyka formuvannya u maybutnikh uchyteliv leksychnoyi kompetentnosti u protsesi navchannya anhliys'koyi movy pislya nimets'koyi: dys. ... kand. ped. nauk: 13.00.02 [Methods of Forming Future Teachers' Lexical Competence in teaching English after German]. Ternopil, 2015. 317 p.

3. Zadorozhna I. P. Teoretyko-metodychni zasady orhanizatsiyi samostiynoyi roboty maybutnikh uchyteliv z ovolodinnya anhlomovnoyu komunikatyvnoyu kompetentsiyeyu. Dokt. Diss. [Theoretical and Methodological Foundations of Future Teachers' Self-Study Work Organization on Acquiring Communicative Competence in English. Doct. Diss.]. Kyiv, 2012. 770 p.

4. Zadorozhna I. P. Developing Language Learning Strategies and Self-Evaluation Skills as Key Factors in Promoting Prospective FL Teachers' Autonomy. Pedahohichnyy almanakh: zbirnyk naukovykh prats. Kherson, 2016. Vol. 29. P. 69-75.

5. Kotlovskyy A. M. Formuvannya anhlomovnoyi leksyko-hramatychnoyi kompetentnosti v hovorinni maybutnikh ekonomistiv u protsesi samostiynoyi roboty: dys. ... kand. ped. nauk: 13.00.02 [Forming Prospective Economists' Lexical and Grammatical Competence in Speaking Within Independent Work]. Ternopil, 2017. 253 p.

6. Bihych O. B., Borysko N. F., Boretska H. E. Metodyka navchannya inozemnykh mov i kultur: teoriya i praktyka [Methods of Teaching Languages and Cltures: Theory and Practice]. S. Yu. Nikolayeva (ed.). Kyiv, Lenvit, 2013. 590 p.

7. Paletska A. V. Metodyka formuvannya nimetskomovnoyi leksychnoyi kompetentnosti maybutnikh uchyteliv na osnovi avtentychnykh khudozhnikh tvoriv: dys. ... kand. ped. nauk: 13.00.02 [Methods of Forming German Lexical Competence of Prospective Teachers on the Basis of Authentic Literary Texts]. Ternopil, 2018. 405 p.

8. Chorna I. Yu. Formuvannya u maybutnikh marketolohiv anhlomovnoyi leksychnoyi kompetentnosti v pys'mi zasobom keys-tekhnolohiyi: dys. ... kand. ped. nauk: 13.00.02 [Forming Prospective Marketers' English Lexical Competence in Written Communication by Means of Case technology]. Ternopil, 2017. $268 \mathrm{p}$.

9. Aitchison J. Words in the Mind: an Introduction to the Mental Lexicon / J. Aitchison. Oxford: Blackwell, 1987. $229 \mathrm{p}$.

10. Aspirin. MedlinePlus. Available at: https://medlineplus.gov/druginfo/meds/a682878.html.

11. Cohen A. D. Strategies in Learning and Using a Second Language. New York: Addison Wesley Longman, 1998. $295 \mathrm{p}$.

12. Common European Framework of References for Languages: learning, teaching, assessment. Companion Volume with new Descriptors. 2018. 235 p. Available at: https://www.coe.int/en/web/common-europeanframework-reference-languages.

13. Györffy M. English for Doctors. IDIÓMA Bt, 2001. 225 p.

14. Hedge T. Teaching and Learning in the Language Classroom / T. Hedge: Oxford, Oxford University Press, 2000. 448p.

15. Mićić S. Languages of medicine - present and future. JAHR. 2013. Vol. 4. No. 7. P. 217-233.

16. Nation P. Teaching Vocabulary. The Asian EFL Journal. 2005. Vol. 7. Issue 3. P. 47-54.

Наукові записки. Серія: педагогіка. - 2018. - № 2. 


\section{ЛІНГВОДИДАКТИКА}

17. O'Malley M. J., Chamot A. U. Learning Strategies in Second Language Acquisition. Cambridge: Cambridge Applied Linguistics, 1990. 276 p.

18. Rubin J. Learner strategies: Theoretical assumptions, research history and typology. Learner Strategies in Language Learning; A. Wenden and J. Rubin (eds). New York: Prentice Hall, 1987. P. 15-30.

19. Takač V. P. Vocabulary Learning Strategies and Second Language Acquisition. Multilingual Matters LTD, 2008. $197 \mathrm{p}$.

20. Williams M., Burden R. L. Psychology for Language Teachers. Cambridge: Cambridge University Press, 1997. $252 \mathrm{p}$.

Стаття надійшла в редакиію 24.05.2018 p. 